\title{
TOKSISITAS LIMBAH CAIR PENCUCIAN UDANG dari PASAR KOBONG, SEMARANG TERHADAP PERTUMBUHAN MIKROALGA Chlorella sp.
}

\author{
Toxicity of Shrimp Liquid Waste Washing from Pasar Kobong, Semarang toward The Growth of Microalgae \\ Chlorella sp.
}

Harry Saxena Saragih, Siti Rudiyanti *), Haeruddin

Program Studi Manajemen Sumberdaya Perairan, Jurusan Perikanan

Fakultas Perikanan dan Ilmu Kelautan, Universitas Diponegoro

Jl. Prof. Soedarto, SH, Tembalang, Semarang, Jawa Tengah - 50275, Telp/Fax. +6224 7474698

Email: harryxena@gmail.com

\begin{abstract}
ABSTRAK
Pasar Kobong merupakan pasar ikan di kawasan Pengapon, Kecamatan Semarang Utara. Kegiatan pengolahan dan penjualan produk perikanan di pasar ini menghasilkan limbah cair yang berasal dari pencucian ikan dan limbah padat yang berasal dari sisa-sisa kulit ikan tersebut. Tujuan dari penelitian ini adalah untuk mengetahui toksisitas dan pengaruh limbah cair pencucian udang terhadap pertumbuhan kultur Chlorella $s p$. Penelitian ini dilakukan pada bulan Maret 2017 di laboratorium Pengelolaan Sumberdaya Ikan dan Lingkungan, Universitas Diponegoro. Metode yang digunakan adalah metode eksperimental laboratoris. Rancangan percobaan menggunakan Rancangan Acak Lengkap. Perlakuan yang diberikan pada media uji Chlorella sp. adalah konsentrasi air limbah 0\%, 12,5\%, 25\%, 50\%, dan 100\%, kemudian dihitung kepadatan akhirnya. Pada penelitian ini juga dilakukan pengukuran parameter DO, amonia, nitrit, dan $\mathrm{H}_{2} \mathrm{~S}$ untuk mengetahui jumlah kandungannya pada limbah cair pencucian udang tersebut. Hasil perhitungan probit stimulasi dengan logaritma konsentrasi limbah kemudian dianalisis menggunakan uji anova dan uji regresi. Hasil uji anova menunjukkan bahwa konsentrasi limbah pencucian udang berpengaruh terhadap pertumbuhan Chlorella sp. Hasil uji regresi menunjukkan bahwa log konsentrasi limbah cair dengan probit stimulasi pertumbuhan Chlorella sp. memiliki hubungan sangat erat dengan nilai $r=0,9345$. Hasil penelitian juga menunjukkan bahwa limbah cair pencucian udang dari pasar Kobong mengandung amonia, nitrit, dan $\mathrm{H}_{2} \mathrm{~S}$ pada setiap konsentrasi perlakuan. Berdasarkan uji toksisitas disimpulkan bahwa limbah cair pencucian udang dari pasar Kobong berpengaruh terhadap pertumbuhan Chlorella sp. dan merangsang pertumbuhan Chlorella sp. Nilai $\mathrm{SC}_{50}$ yang diperoleh pada penelitian ini adalah $40,50 \%$.
\end{abstract}

Kata kunci: Chlorella sp; toksisitas; limbah cair udang; pertumbuhan Chlorella sp.

\begin{abstract}
Pasar Kobong is a fish market in Pengapon area, North Semarang Subdistrict. The activity in this market produce liquid wastes derived from fish wash and solid waste derived from the remains of the fish skin. The purpose of this study was to know the toxicity and effect of waste shrimp washing to the growth of Chlorella sp. This study was conducted on March 2017 in the laboratory of Fish Resources and Environmental Management, Diponegoro University. This study used a laboratory experimental method. The method used is a laboratory experimental method. Treatment given on Chlorella sp. were the concentration of wastewater $0 \%, 12.5 \%, 25 \%$, 50\%, and $100 \%$, then calculated its final density. This study also measured parameters DO, ammonia, nitrite, and $\mathrm{H}_{2} \mathrm{~S}$ to know the amount of its content in the waste shrimp washing. The result of stimulation probit with logarithm of waste concentration then analyzed using anova test and regression test. Anova test showed that the concentration of shrimp wash waste was affect the growth of Chlorella sp. Regression test show that the log of concentration of liquid waste with stimulation probit of growth of Chlorella sp. has a very close relationship with the value of $r=$ 0.9345. The research also showed that the shrimp liquid waste from Pasar Kobong contains ammonia, nitrite, and $\mathrm{H}_{2} \mathrm{~S}$ at each treatment concentration. Based on toxicity tests can be concluded that the waste liquid washing shrimp affect and stimulate the growth of Chlorella sp. SC 50 value obtained in this study was 40,50\%.
\end{abstract}

Keywords: Chlorella sp; toxicity; shrimp liquid waste; growth of Chlorella sp.

${ }^{\odot}$ Copyright by Management of Aquatic Resources (MAQUARES) 


\section{*) Penulis Penanggungjawab}

\section{PENDAHULUAN}

Indonesia memiliki sumberdaya perikanan yang sangat potensial baik perikanan budidaya, penangkapan, dan pengolahan. Sumberdaya tersebut sangat mendukung peningkatan pendapatan masyarakat, pendapatan daerah, dan pendapatan nasional. Perkembangan dan peningkatan produksi perikanan tidak hanya di sektor budidaya dan penangkapan tetapi juga pada sektor pengolahan ikan. Menurut Heruwati (2002), sektor perikanan merupakan andalan utama sumber pangan dan gizi Indonesia.

Di Indonesia saat ini ada sekitar 170 pengolahan udang dengan kapasitas produksi terpasang sekitar 500.000 ton per tahun. Proses pembekuan udang (cold storage) dalam bentuk udang beku headless atau peeled untuk ekspor, 60-70\% dari berat udang jadi limbah (bagian kulit dan kepala). Diperkirakan, dari proses pengolahan oleh seluruh unit pengolahan yang ada, akan dihasilkan limbah sebesar 325.000 ton per tahun. Limbah sebanyak itu, jika tidak ditangani secara tepat, akan menimbulkan dampak negatif bagi lingkungan sebab limbah tersebut dapat meningkatkan biological oxygen demand dan chemical oxygen demand (Prasetiyo, 2006).

Limbah dari pencucian udang mengandung nutrisi. Nutrisi tersebut berasal dari kandungan protein dan senyawa organik yang terdapat pada limbah udang. Limbah udang mengandung protein kasar sekitar 25-40 \%, dan kalsium karbonat 45-50 \% (Muzzarelli et al., 2000). Limbah yang mengandung nutrien akan memacu pertumbuhan Chlorella sp dan bahkan menyebabkan dapat blooming Chlorella sp tersebut.

Alga merupakan salah satu biota yang dapat dijadikan sebagai parameter untuk mendeteksi tingkat racun dalam badan perairan. Chlorella sp adalah salah satu jenis alga yang dapat dijadikan sebagai parameter pengukuran tingkat toksik. Hal ini karena Chlorella $s p$ mudah ditemukan, banyak dikultur, mudah dalam membudidayakan, (Nakayama, 1992). Penelitian ini dilakukan untuk melihat dan mengetahui toksisitas limbah cair hasil pencucian udang terhadap Chlorella sp. yang dikultur di laboratorium.

Penelitian ini dilakukan pada bulan Maret 2017 di Laboratorium Pengelolaan Sumberdaya Ikan dan Lingkungan, Universitas Diponegoro. Tujuan dilakukannya penelitian ini adalah sebagai berikut:

1. Mengetahui pengaruh limbah pencucian udang terhadap pertumbuhan Chlorella sp.

2. Mengetahui toksisitas limbah pencucian udang terhadap pertumbuhan Chlorella sp.

3. Mengetahui konsentrasi inhibisi atau stimulasi limbah pencucian udang terhadap pertumbuhan Chlorella $s p$.

\section{MATERI DAN METODE PENELITIAN}

Materi yang digunakan dalam penelitian ini adalah limbah cair pencucian udang yang diambil dari para pedagang ikan di pasar Kobong, Semarang. Alat yang digunakan pada penelitian ini adalah alumunium foil digunakan untuk menutup botol sampel, botol Erlenmeyer digunakan sebagai wadah uji, haemocytometer dan kaca penutup yang digunakan sebagai tempat alga saat perhitungan, inkubator digunakan sebagai tempat penyimpanan media selama uji, kertas label digunakan untuk memberi label, mikroskop untuk melihat dan menghitung kepadatan Chlorella sp., dan pipet tetes untuk mengambil alga dan nutrien. Bahan yang digunakan dalam penelitian ini adalah limbah pencucian udang sebagai bahan uji, kultur Chlorella sp. Sebagai bahan uji, dan larutan Walne sebagai nutrien.

Metode yang digunakan pada penelitian ini adalah metode eksperimental laboratoris. Metode eksperimental laboratoris merupakan suatu penelitian dengan pengamatan dan perencanaan secara teratur terhadap fenomena yang diteliti (Supranto, 2003).

Rancangan percobaan yang digunakan adalah Rancangan Acak Lengkap (RAL). Rancangan acak lengkap dilakukan dengan memberikan beberapa perlakuan pada biota uji dalam konsentrasi limbah cair yang berbeda, serta dengan pengulangan masing-masing konsentrasi. Penelitian ini menggunakan metode Rancangan Acak Lengkap (RAL) karena unit percobaan yang digunakan bersifat homogen dan perlakuan dilakukan secara acak terhadap unit-unit percobaan tersebut.

Rancangan ini dilakukan dengan memberikan 5 perlakuan dengan 3 kali pengulangan. Perlakuan pada penelitian ini meliputi air sebagai media hidup Chlorella sp., dengan konsentrasi limbah 0\% (kontrol), 12,5\%, $25 \%, 50 \%$, dan $100 \%$. Selang konsentrasi uji ini didapatkan berdasarkan U.S. Environmental Protection Agency, (2002). Penelitian ini dilakukan dengan tahapan:

\section{a. Penyediaan Limbah Cair Pencucian Udang}

Sampel yang digunakan pada penelitian ini adalah limbah cair dari pencucian udang yang diperoleh dari hasil pencucian udang dari para pedagang di pasar Kobong. Cara para pedagang mencuci udang adalah mencuci dengan air statis di ember dengan perbandingan air dengan udang adalah 1:1.

\footnotetext{
${ }^{\circledR}$ Copyright by Management of Aquatic Resources (MAQUARES)
} 


\section{b. Penyediaan Chlorella sp}

Chlorella sp yang digunakan pada penelitian ini diperoleh dari Balai Besar Perikanan Budidaya Air Payau (BBPBAP) Jepara.

\section{c. Uji Toksisitas Chlorella sp.}

Uji toksisitas dilakukan dengan memberikan 5 perlakuan dengan 3 kali pengulangan. Perlakuan pada penelitian ini meliputi air sebagai media hidup Chlorella sp., dengan konsentrasi limbah 0\% (kontrol), 12,5\%, $25 \%, 50 \%$, dan $100 \%$.

Uji toksisitas terhadap alga Chlorella sp. dilakukan dengan menghitung kepadatan awal alga dengan menggunakan rumus:

$$
\text { Kepadatan sel }(\mathrm{sel} / \mathrm{ml})=\frac{\frac{n}{400} \times 1000}{0.00025}
$$

Keterangan: $\mathrm{n}=$ jumlah sel yang diperoleh pada saat pengamatan.

Setelah mendapatkan nilai kepadatan awal kemudian dilakukan uji toksisitas, untuk setiap konsentrasi uji volume media uji adalah $100 \mathrm{~mL}$, dimana volume tersebut terdiri dari air limbah, larutan kultur Chlorella sp.

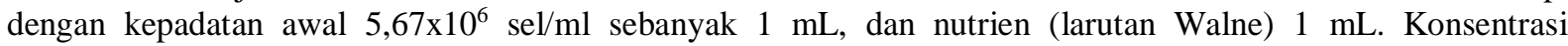
pengenceran media uji didapat dengan menambahkan air yang sudah disterilisasi sesuai dengan konsentrasi pengenceran yang diinginkan yaitu konsentrasi 12,5\%, 25\%, dan 50\%. Sedangkan untuk konsentrasi $0 \%$ adalah air yang sudah disterilisasi. Setelah melakukan uji toksisitas kemudian menghitung kepadatan akhir dengan menggunakan rumus yang sama pada saat menghitung kepadatan awal.

\section{d. Pengukuran Konsentrasi Oksigen Terlarut (DO), Derajat Keasaman (pH), Amonia, Nitrit, dan $\mathrm{H}_{2} \mathrm{~S}$ pada \\ Media Percobaan}

Pada penelitian ini diukur juga kandungan okisgen Terlarut (DO), amonia, nitrit, dan $\mathrm{H}_{2} \mathrm{~S}$ pada setiap konsentrasi perlakuan. Data oksigen terlarut (DO), diukur setiap pagi dan sore hari selama penelitian dan diukur pada semua media percobaan yang berisi limbah. Sedangan data amonia (NH3), nitrit (NO3), dan Hidrogen Sulfida $\left(\mathrm{H}_{2} \mathrm{~S}\right)$ diukur hanya pada awal penelitian yaitu sebelum melakukan uji toksisitas dengan cara membuat duplikat dengan konsentrasi pengenceran limbah yang sama dengan yang digunakan untuk uji toksisitas. Kandungan Amonia, Nitrit, dan $\mathrm{H}_{2} \mathrm{~S}$ hanya diukur pada konsentrasi pengenceran yang mengandung limbah cair pencucian udang yaitu konsentrasi 12,5\%, 25\%, $50 \%$, dan $100 \%$. Kandungan oksigen terlarut (DO) diukur sendiri selama penelitian di Laboratorium Pengelolaan Sumberdaya Ikan dan Lingkungan, Universitas Diponegoro, dengan menggunakan DO meter, sedangkan uji amonia, uji nitrit dan uji $\mathrm{H}_{2} \mathrm{~S}$ dilakukan di Laboratorium Balai Pengujian dan Peralatan, Dinas Pekerjaan Umum Bina Marga dan Cipta Karya Pemerintah Provinsi Jawa Tengah, di Jl. Murbei I Timur, Srondol Timur, Semarang dengan metode yang digunakan adalah sebagai berikut: Uji amonia (SNI 06-6989.30-2005), uji Sulfida (Spectrofotometer DR 2100), dan uji Nitrit (SNI 06-6989.9-2004).

\section{Analisis Data}

Sebelum melakukan analisis data, persentase penghambatan/inhibisi terhadap pertumbuhan algae relatif terhadap kontrol dihitung terlebih dahulu dengan menggunakan rumus sebagai berikut:

$$
\begin{array}{ll}
\mathrm{I} \%=\frac{C-T}{C} \times 100, & \sum \text { jika } \mathrm{T}<\mathrm{C} \\
\mathrm{S} \%=\frac{T-C}{C} \times 100, & \sum \text { jika } \mathrm{T}>\mathrm{C}
\end{array}
$$

Keterangan:
I: Inhibisi
T: Kepadatan alga pada media uji (sel/ml)
S: Stimulasi
C: Kepadatan alga pada media kontrol ( $\mathrm{sel} / \mathrm{ml})$

Data persentase inhibisi/stimulasi kemudian akan diuji dengan uji normaitas dan homogenitas menggunakan spss sehingga memenuhi syarat untuk melanjutkan penentuan nilai probit inhibisi/stimulasi. Data probit inhibisi/stimulasi kemudian ditransfomasilan secara manual ke dalam table probit untuk memperoleh nilai probit inhibisi/stimulasi. Hasil probit inhibisi/stimulasi kemudian digunakan sebagai variabel y, sedangkan logaritma konsentrasi limbah cair digunakan sebagai variabel x. 
Kemudian dilakukan uji anova untuk mengetahui pengaruh dari konsentrasi limbah cair pencucian udang pada media uji terhadap pertumbuhan Chlorella sp., dengan hipotesis:

$\mathrm{H}_{0}$ : Perbedaan konsentrasi limbah cair pencucian udang tidak berpengaruh terhadap pertumbuhan Chlorella sp.

$\mathrm{H}_{1}$ : Perbedaan konsentrasi limbah cair pencucian udang berpengaruh terhadap pertumbuhan Chlorella $s p$.

. Setelah itu dilakukan analisis regresi korelasi untuk mengetahui hubungan antara logaritma konsentrasi limbah dengan probit inhibisi/stimulasi Chlorella sp. Persamaan regresi yang diperoleh kemudian akan digunakan untuk menentukan nilai $\mathrm{IC}_{50}$ atau $\mathrm{SC}_{50}$ limbah cair pencucian udang.

\section{HASIL DAN PEMBAHASAN}

\section{Uji toksisitas Chlorella $s p$}

Hasil penelitian yang diperoleh setelah melakukan uji toksisitas limbah cair terhadap Chlorella sp. dengan kepadatan awal 5,66 x106 sel/ml, dengan menggunakan konsentrasi limbah cair 0\%, 12,5\%, 25\%, 50\%, dan 100\% dengan 3 kali pengulangan. Histogram rata-rata kepadatan akhir Chlorella sp. tersaji pada Gambar 1.

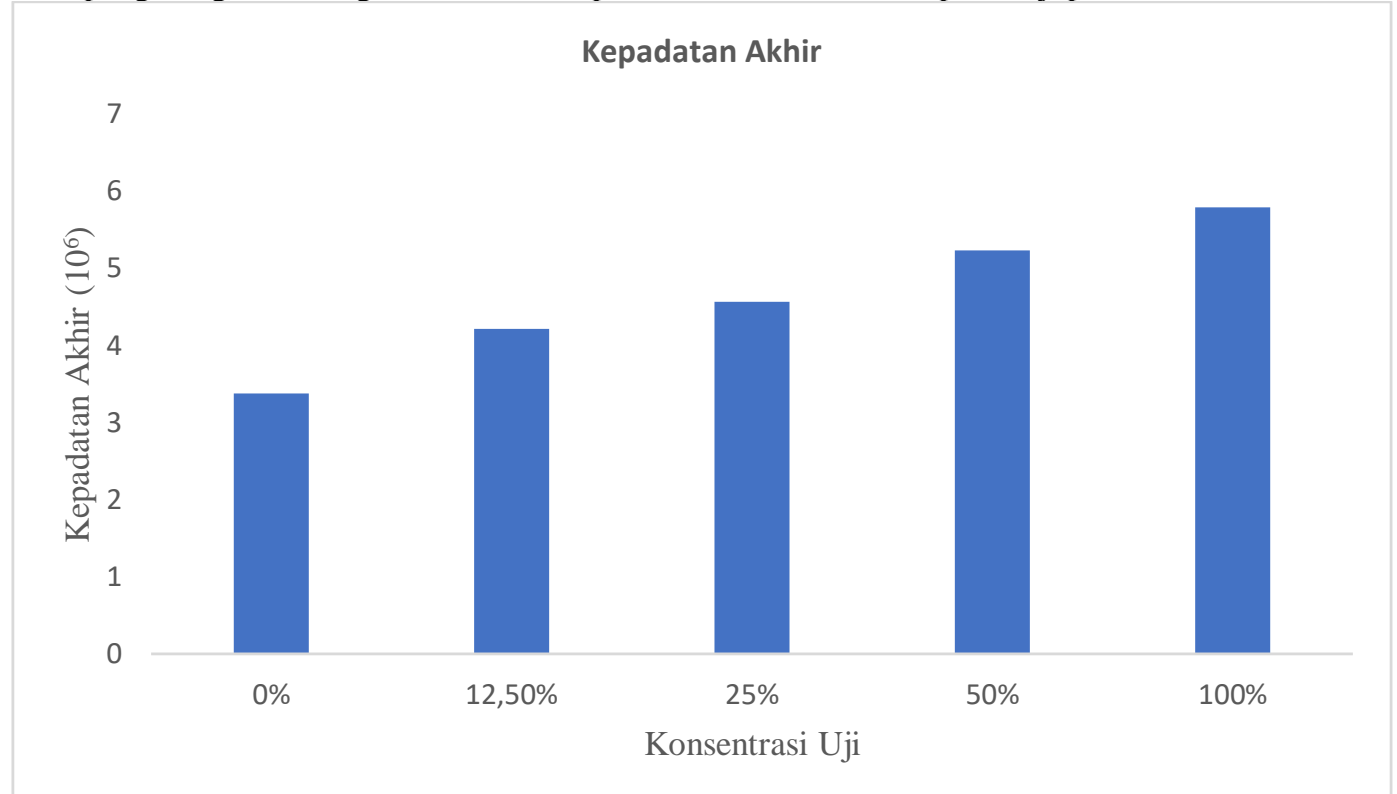

Gambar 1. Histogram hasil kepadatan akhir uji tokisitas limbah cair pencucian udang terhadap kultur Chlorella sp.

Berdasarkan histogram di atas, dapat dilihat bahwa kepadatan Chlorella sp pada media uji lebih tinggi dibandingkan dengan kepadatan Chlorella sp pada konsentrasi $0 \%$ (media kontrol). Hal ini menunjukkan bahwa limbah cair dari Pasar Kobong merangsang atau menstimulasi pertumbuhan Chlorella sp.

Peningkatan kepadatan pada wadah uji yang mengandung limbah pencucian udang diduga disebabkan oleh karena limbah pencucian udang tersebut mengandung nutrien. Nutrien pada limbah tersebut kemugkinan dipengaruhi oleh adanya kandungan oksigen terlarut (DO), nitrit, protein, dan juga lemak pada limbah tersebut. Menurut Mendez et al, (1992) dalam Sari (2005), limbah cair industri perikanan memiliki kandungan nutrien, minyak, dan lemak yang tinggi sehingga menyebabkan tingginya nilai COD, terutama berasal dari proses penyiangan usus dan isi perut serta proses pemasakan.

Hasil penelitian menunjukkan bahwa limbah pencucian udang dari pasar Kobong memiliki kandungan amonia, nitrit, dan $\mathrm{H}_{2} \mathrm{~S}$. Kandungan ini yang diduga mempengaruhi peningkatan kepadatan Chlorella sp. pada wadah uji yang mengandung limbah pada berbagai konsentrasi. Hal ini sesuai dengan pernyataan Kaswinarni (2007), yang menyatakan bahwa Chlorella sp. memperoleh energi dari sinar matahari dan menggunakan bahan anorganik seperti karbondioksida, amonia, nitrat, dan fosfat dalam sintesis sel-sel tambahan.

Amonia bersifat racun bagi mikroalga, namun berbeda halnya jika amonia yang tinggi disertai dengan $\mathrm{pH}$ $<7$, maka akan terjadi proses ionisasi amonia yang pada akhir prosesnya akan menghasilkan amonium. Amonium inilah yang merupakan sumber nutrien bagi mikroalga tersebut (Oh-Hama et al, 1988 dalam Irianto, 2011).

Adanya kandungan bahan organik pada limbah yang digunakan pada penelitian menyebabkan meningkatnya kepadatan akhir Chlorella sp. Air limbah dari kegiatan perikanan memiliki kandungan nitrogen, fosfor, dan kalium. Kandungan ini hampir sama dengan kandungan pupuk yang biasa digunakan untuk kultur alga ${ }^{\circ}$ Copyright by Management of Aquatic Resources (MAQUARES) 
yaitu pupuk Walne. Pada pupuk Walne memiliki kandungan nitrogen $0,0169 \mathrm{~g} / \mathrm{L}$, dan fosfor $0,004 \mathrm{~g} / \mathrm{L}$, kandungan ini hampir sama dengan kandungan dari limbah cair kegiatan perikanan (Meritasari, 2012).

Setelah melakukan uji normalitas dan homogenitas terhadap data persentase stimulasi, diketahui bahwa data yang didapat menyebar normal dengan masing-masing pengulangan memiliki nilai 0,200 serta bersifat homogen dengan nilai 0,182 (Sig. > 0,05), sehingga dapat memenuhi syarat untuk melanjutkan transformasi data persentase stimulasi ke dalam tabel probit dan juga sebagai syarat untuk melakukan uji anova. Hasil analisis menggunakan uji anova diketahui bahwa nilai signifikansi 0,000 (Sig. $<0,05)$ yang berati konsentrasi limbah berpengaruh terhadap pertumbuhan Chlorella sp.

Hasil analisis regresi antara log konsentrasi limbah cair dengan nilai probit persentase stimulasi pertumbuhan terhadap Chlorella $s p$. menunjukkan hubungan yang cukup kuat dengan nilai yang diperoleh adalah $\mathrm{r}=0,9345$. Persamaan regresi yang diperoleh adalah $\mathrm{y}=1,4489 \mathrm{x}+2,6709$, dengan $\mathrm{a}=2,6709$ dan $\mathrm{b}=1,4489 \mathrm{x}$. Hasil uji regresi antara log konsentrasi limbah cair dengan nilai probit stimulasi pertumbuhan terhadap Chlorella $s p$. dapat dilihat pada Gambar 2

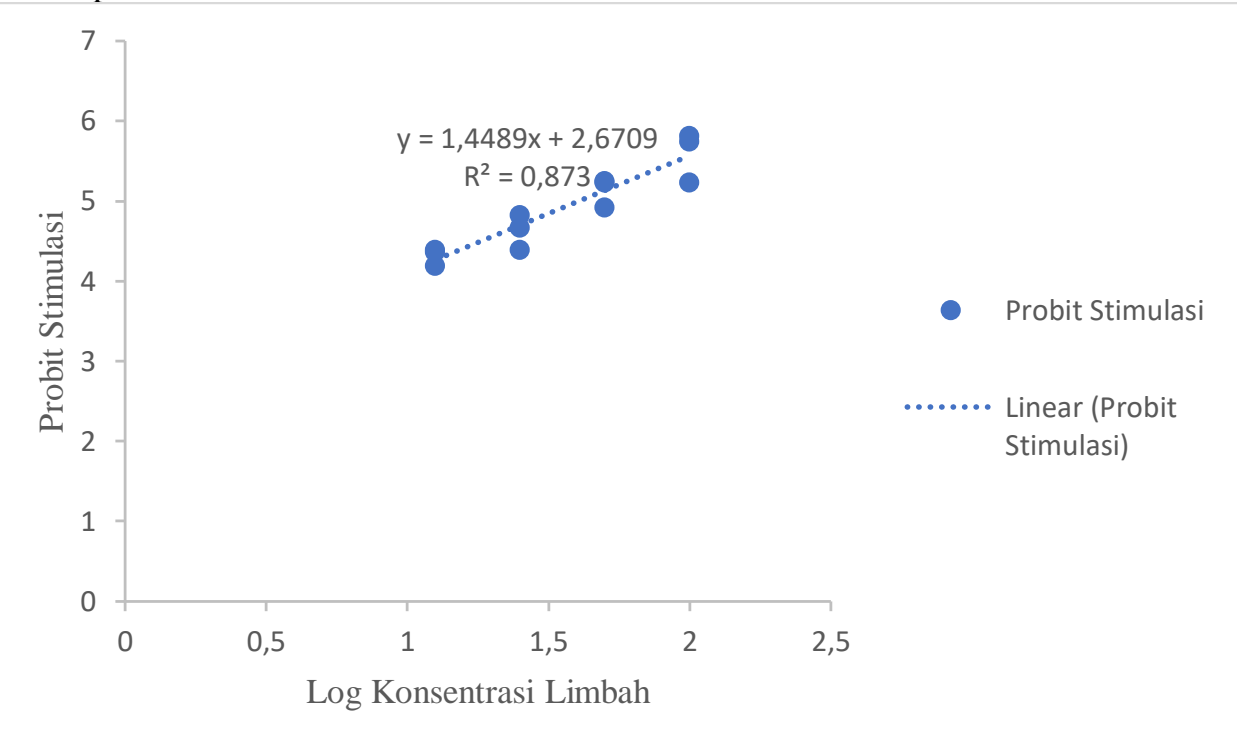

Gambar 2. Hasil Uji Regresi antara Log Konsentrasi Limbah Cair dengan Nilai Probit Stimulasi Pertumbuhan Chlorella sp.

Berdasarkan gambar di atas, dapat diketahui bahwa terdapat hubungan antara log konsentrasi limbah cair dengan nilai probit stimulasi pertumbuhan Chlorella sp. semakin tinggi nilai log konsentrasi limbah maka semakin tinggi juga nilai probit stimulasi Chlorella $s p$. Dengan menggunakan persamaan regresi tersebut diatas, dapat ditentukan konsentrasi stimulasi limbah cair pencucian udang adalah sebesar 40,50\%

\section{Pengukuran Kandungan Oksigen Terlarut (DO)}

Kandungan oksigen terlarut diukur pada pagi hari pukul 09.00 WIB dan pada sore hari pukul 15.00 WIB selama penelitian. Berdasarkan hasil pengukuran selama penelitian, didapatkan nilai kandungan oksigen terlarut meningkat meskipun dalam jumlah yang relatif kecil dari hari pertama hinga hari ke-4. Histogram kandungan DO pada pagi hari dan sore hari pada setiap wadah uji tersaji pada Gambar 3 dan 4 berikut. 


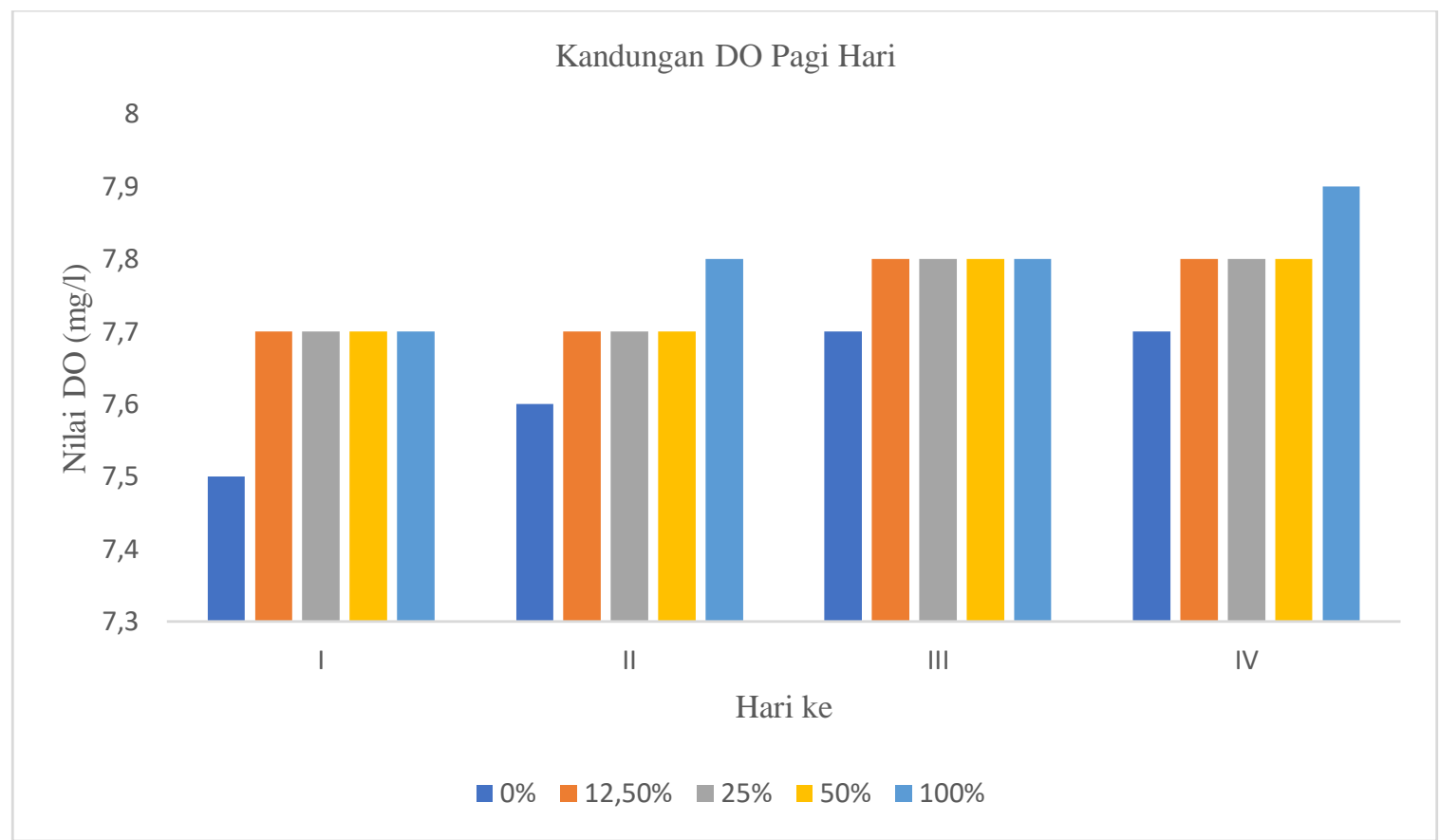

Gambar 3. Histogram Kandungan DO pada Pagi Hari

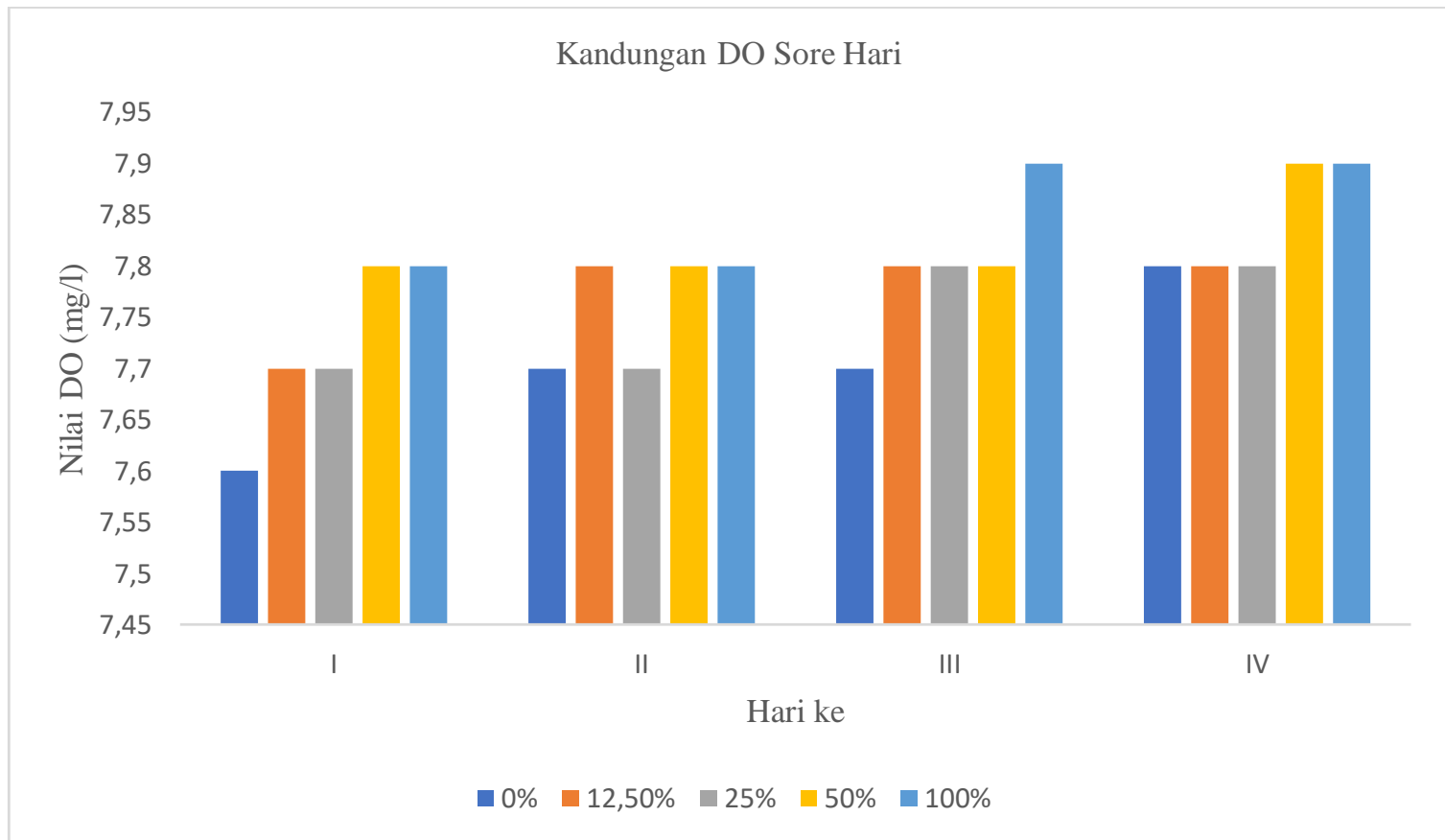

Gambar 4. Histogram Kandungan DO pada Sore Hari

Berdasarkan hasil penelitian, kandungan oksigen terlarut (DO) tertinggi selama penelitian stabil dan bahkan meningkat dalam jumlah yang relatif sedikit. Hal ini diduga disebabkan adanya klorofil pada Chlorella $s p$. yang menyebabkan Chlorella sp. dapat melakukan proses fotosintesis dengan bantuan cahaya. Hal ini sesuai dengan pernyataan Pitriana et al (2008), yang mrnyatakan bahwa Chlorella sp. merupakan kelompok organisme protista autotrof, yakni protista yang mampu membuat makanannya sendiri, karena organisme ini mempunyai pigmen klorofil, sehingga dapat melakukan fotosintesis.

${ }^{\odot}$ Copyright by Management of Aquatic Resources (MAQUARES) 
Kristanto (2004) juga menyatakaan bahwa, oksigen terlarut dapat berasal dari fotosintesis tanaman air dan dari atmosfir (udara) yang masuk ke dalam air dengan kecepatan tertentu. Kadar oksigen akan lebih tinggi karena adanya proses difusi antara air dengan udara bebas serta adanya proses fotosintesis. Dan Salmin (2000), menyatakan bahwasumber utama oksigen dalam suatu perairan berasal dari suatu proses difusi dari udara bebas dan hasil fotosintesis organisme yang hidup dalam perairan tersebut.

\section{Nilai Derajat Keasaman (pH)}

Nilai derajat keasaman $(\mathrm{pH})$ diukur pada pagi hari pukul 09.00 WIB dan pada sore hari pukul 15.00 WIB selama penelitian. Berdasarkan tabel 8, diperoleh bahwa kandungan $\mathrm{pH}$ selama uji toksistas mengalami peningkatan. Nilai kandungan $\mathrm{pH}$ di awal uji toksisitas adalah 6 sedangkan pada akhir uji toksisitas diperoleh kandungan $\mathrm{pH}$ sebesar 7. Histogram kandungan $\mathrm{pH}$ pagi hari dan sore hari selama uji toksisitas dapat dilihat pada Gambar 5 dan 6 berikut:

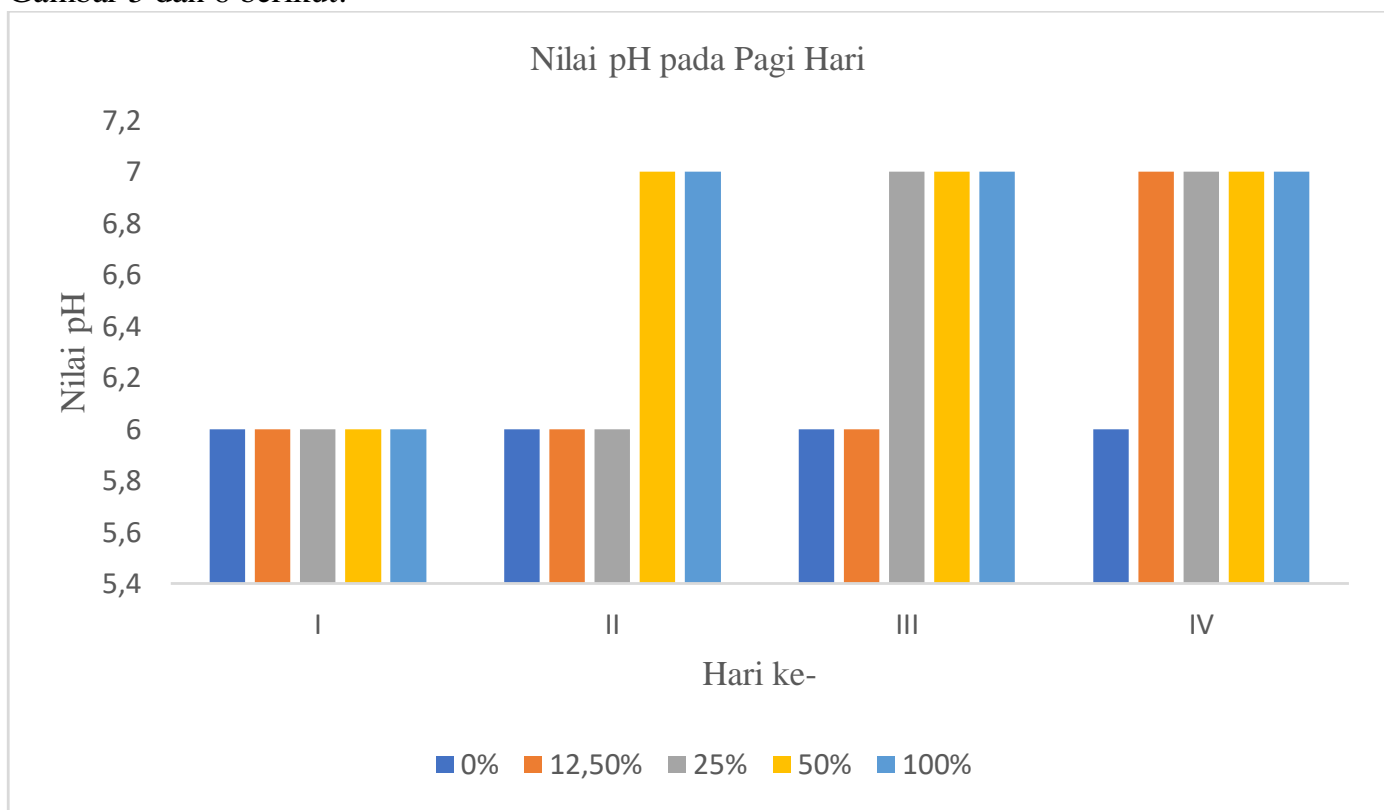

Gambar 5. Histogram Kandungan pH pada Pagi Hari

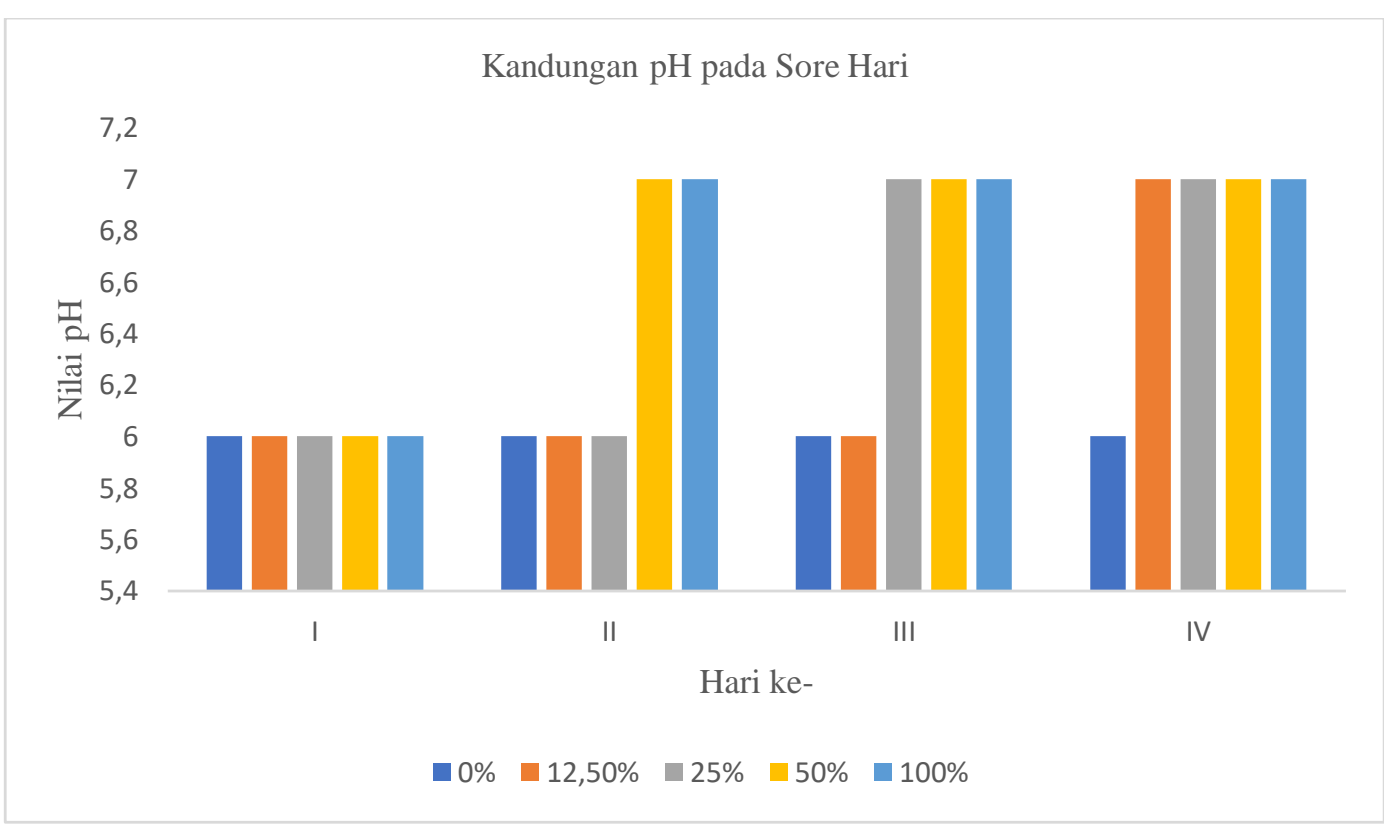

${ }^{\circledR}$ Copyright by Management of Aquatic Resources (MAQUARES) 
Gambar 6. Histogram Kandungan pH pada Sore Hari

Berdasarkan penelitian diperoleh hasil bahwa kandungan $\mathrm{pH}$ mengalami peningkatan selama penelitian. Pada awal penelitan kandungan $\mathrm{pH}$ adalah 6 dan pada akhir penelitian meningkat menjadi 7. Semakin tinggi konsentrasi limbah menyebabkan semakin tinggi kepadatan Chlorella $s p$. dan wadah uji yang semakin tinggi kepadatan akhirnya mengalami kenaikan $\mathrm{pH}$ tercepat. Nilai $\mathrm{pH}$ selama penelitian masih optimum untuk pertumbuhan kultur Chlorella sp., hal ini sesuai dengan pernyataan Nielsan (1995) dalam Prihantini at al, (2005), yang menyatakan bahwa pada umumnya strain Chlorella mampu bertoleransi terhadap kisaran salinitas dan $\mathrm{pH}$ yang cukup lebar. pH yang sesuai untuk pertumbuhan Chlorella sp. berkisar antara 4,5 - 9,3.

Peningkatan nilai pH selama penelitan diduga disebabkan oleh peningkatan kepadatan Chlorella sp. Hal ini sesuai dengan pernyataan Wijanarko et al, (2007) yang menyatakan bahwa semakin tinggi kerapatan sel pada medium kultur menyebabkan kondisi medium kultur meningkat tingkat kebasaannya ( $\mathrm{pH}$ semakin tinggi) dan hal itu menyebabkan peningkatan $\mathrm{CO}_{2}$ terlarut dalam medium kultur.

\section{Pengukuran Amonia, Nitrit, dan $\mathrm{H}_{2} \mathrm{~S}$ pada Konsentrasi yang Mengandung Limbah}

Hasil uji amonia, uji nitrit, dan uji $\mathrm{H}_{2} \mathrm{~S}$ sebelum dan setelah uji toksisitas pada media uji yang mengandung limbah pencucian udang dapat dilihat pada Gambar berikut:

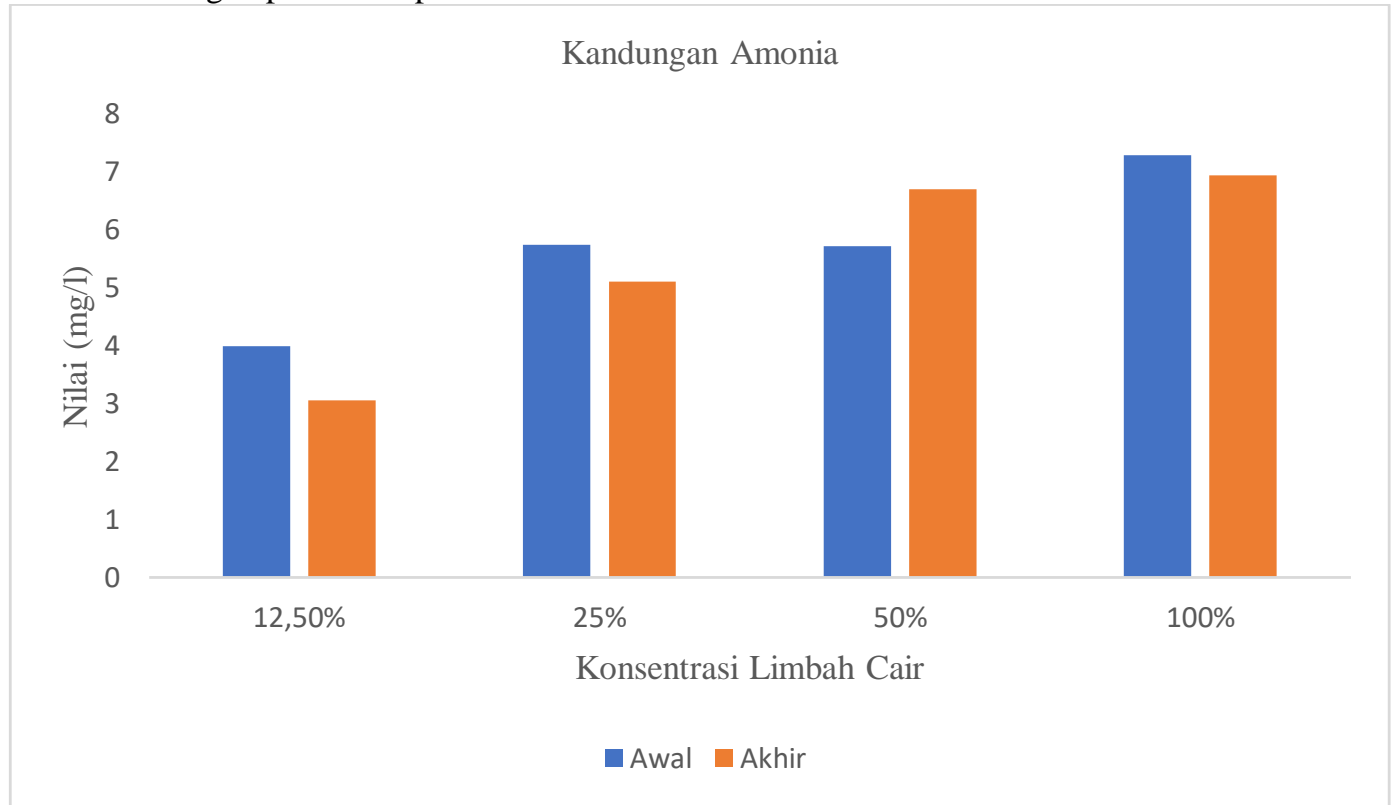

Gambar 7. Histogram Kandungan Amonia, di Awal dan Akhir Uji Toksisitas pada Setiap Wadah Uji yang Mengandung Limbah Pencucian Udang 


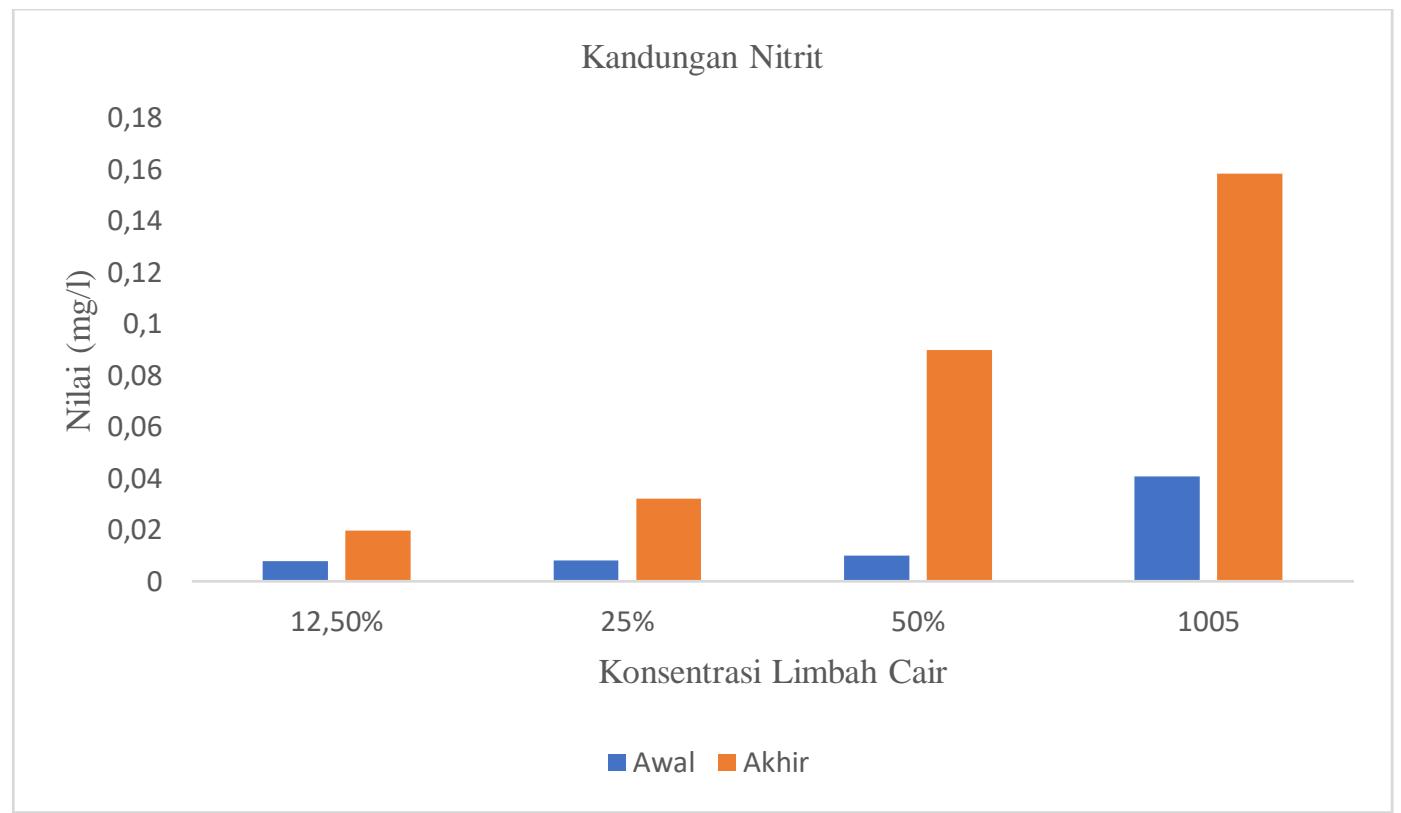

Gambar 8. Histogram Kandungan Nitrit, di Awal dan Akhir Uji Toksisitas pada Setiap Wadah Uji yang Mengandung Limbah Pencucian Udang

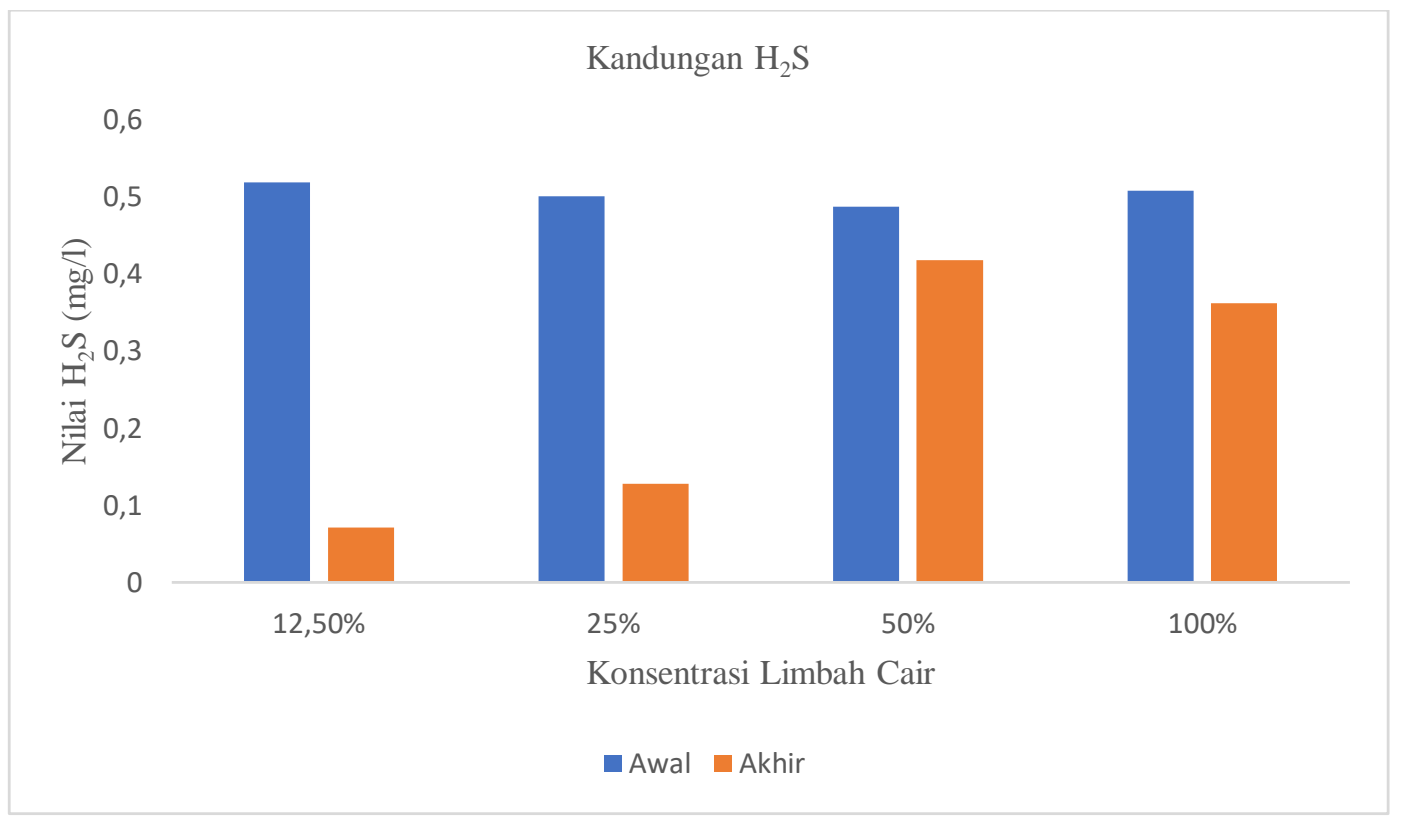

Gambar 9. Histogram Kandungan $\mathrm{H}_{2} \mathrm{~S}$ di Awal dan Akhir Uji Toksisitas pada Setiap Wadah Uji yang Mengandung Limbah Pencucian Udang

Berdasarkan penelitian hasil uji amonia pada limbah cair sebelum penelitian lebih besar dibandingkan dengan jumlah amonia setelah penelitan. Hal ini diduga disebabkan karena Chlorella sp. menggunakan amonia yang terdapat pada limbah pada limbah cair pencucian udang sebagai sumber energi untuk pertumbuhannya. Hal ini sesuai dengan pernyataan Kaswinarni (2007), menyatakan bahwa Chlorella sp. memperoleh energi dari sinar matahari dan menggunakan bahan anorganik seperti karbondioksida, amonia, nitrat, dan fosfat dalam sintesis selsel tambahan. Penurunan kadar amonia tersebut juga diduga disebabkan oleh terjadinya proses nitrifikasi. Hal ini sesuai dengan pernyataan Manalu (2010), yang menyatakan bahwa penurunan kadar $\mathrm{NH}_{3}$ terjadi karena terjadinya proses nitrifikasi sehingga terbentuk untuk pertumbuhan mikroalga.

\footnotetext{
${ }^{\odot}$ Copyright by Management of Aquatic Resources (MAQUARES)
} 
Nilai kandungan nitrit yang diperoleh berdasarkan hasil penelitian adalah kandungan nitrit mengalami peningkatan seirng dengan bertambahnya konsentrasi limbah. Hal itu diduga disebabkan oleh proses nitrifikasi dari amonia yang menghasilkan senyawa nitrit. Hal ini sesuai dengan pernyataan Manalu (2010), yang menyatakan bahwa penurunan kadar $\mathrm{NH}_{3}$ terjadi karena terjadinya proses nitrifikasi sehingga terbentuk NO3 yang menjadi sumber nutrien untuk pertumbuhan mikroalga. Menurut Ida (2009), nitrit biasanya ditemukan dalam jumlah yang sangat sedikit, karena bersifat tidak stabil dengan keberadaan oksigen. Pada reduksi nitrat oleh aktivitas mikroba dalam kondisi anerob, dapat menghasilkan gas amonia dan gas-gas lain seperti $\mathrm{N}_{2} \mathrm{O}, \mathrm{NO}_{2}, \mathrm{NO}$, dan $\mathrm{N}_{2}$. Nitrit yang berasal dari nitrogen pada dasarnya akan mendukung pertumbuhan alga termasuk Chlorella sp. Pada penelitian ini juga nitrit berpengaruh sebagai perangsang pertumbuhan Chlorella sp. Hal ini sesuai dengan pendapat Vashista (1979) dalam Rostini (2007), yang menyatakan nitrogen merupakan komponen utama pembentuk protein dan unsur yang penting untuk menyokong pertumbuhan dari sel alga.

Berdasarkan penelitian yang dilakukan, nilai kandungan $\mathrm{H}_{2} \mathrm{~S}$ pada limbah pencucian udang pada awal uji lebih tinggi dibandingkan dengan akhir uji. Kandungan hidrogen sulfida $\left(\mathrm{H}_{2} \mathrm{~S}\right)$ tidak terlalu berpengaruh terhadap kepadatan akhir Chlorella sp. Kandungan $\mathrm{H}_{2} \mathrm{~S}$ pada limbah menyebabkan bau yang sangat menyengat pada sampel penelitian. Hal ini sesuai dengan pernyataan Setyono, et al, (2008) yang menyatakan bau yang menyengat tersebut ditimbulkan oleh senyawa-senyawa pencemar, salah satunya ialah sulfida.

\section{KESIMPULAN}

Kesimpulan yang dapat diambil berdasarkan penelitian adalah limbah cair pencucian udang berpengaruh terhadap pertumbuhan Chlorella sp. dan bersifat sebagai stimulus atau perangsang pertumbuhan Chlorella sp. Nilai $\mathrm{SC}_{50}$ yang diperoleh pada peneitian ini adalah 40,50\% yang berarti konsentrasi limbah yang dibutuhkan untuk menstimulasi pertumbuhan Chlorella sp. sebanyak 50\% adalah sebesar 40,50\%.

\section{UCAPAN TERIMA KASIH}

Penulis mengucapkan terima kasih kepada Ir. Siti Rudiyanti, M.Si, Dr. Ir. Haeruddin, M.Si dan Prof. Dr. Ir. Djoko Suprapto, D.E.A yang telah memberikan saran, petunjuk serta waktunya dalam penyusunan laporan penelitian.

\section{DAFTAR PUSTAKA}

Heruwati, ES. 2002. Pengolahan Ikan secara Tradisional: Prospek dan Peluang Pengembangan. Jakarta. Departemen Pertanian.

Ida, Y. HRP. 2009. Penentuan Kadar Amonia Pada Beberapa Air Sungai di Kota Medan Dengan Menggunakan Metode Spektrofotometri (visible). Universitas Sumatra Utara. Medan.

Irianto, D. 2011. Pemanfaatan Mikroalga Laut Scenedesmus sp Sebagai Penyerap Bahan Kimia Berbahaya Dalam Air Limbah Industri. [Skripsi]. Fakultas Teknologi Ilmu Pertanian Bogor, Bogor, 46 hlm.

Kaswinarni, F. 2007. Kajian Teknis Pengolahan Limbah Padat dan Cair Industri Tahu. $\quad$ [Tesis]. Universitas Diponegoro, Semarang, 97 hlm.

Kristanto P. 2004. Ekologi Industri. Surabaya: Penerbit Andi.

Manalu, Suryana. 2010. Karakterisasi Pertumbuhan Mikroalga dan Eliminasi Nutrien dari Limbah Cair Peternakan dengan Sistem Semi Kontinu. [Skripsi]. Fakultas Teknologi Pertanian, Institut Pertanian Bogor, Bogor, $78 \mathrm{hlm}$.

Meritasari, Diana. 2012. Pengaruh Pemberian Pupuk Cair Limbah Ikan Lemuru (Sardinella sp.) dengan Dosis yang Berbeda Terhadap Pertumbuhan Chlorella sp. Jurnal Ilmiah Perikanan dan Kelautan Vol. 4 No. 1

Muzzarelli, R.A.A and P.P. Joles. 2000. Chitin and Chitinases; Biochemistry of Chitinase.Switzerland,Bikhauser Verlag.

Nakayama. 1992. Scientific Report on Chlorella in Japan. Kyoto: Silpaque Publishing Inc.

\footnotetext{
${ }^{\odot}$ Copyright by Management of Aquatic Resources (MAQUARES)
} 
Pitriana, P. Dan Rahmatia, D., 2008, Bioekspo, Menjelajah Alam dengan Biologi, Jatra Graphics: Solo

Prasetiyo K. 2006. Pengolahan Limbah Cangkang Udang. www.kompas.com. [2 September].

Prihantini, N. B., Putri. B. dan Ratna. Y. 2005. Pertumbuhan Chlorella spp. dalam Medium Ekstrak Tauge (MET) dengan Variasi pH Awal. Departemen Biologi. Fakultas MIPA. Universitas Indonesia, Depok, 9 (1): 3-4

Rostini, I., 2007, Kultur Fitoplankton (Chlorella sp., dan Tetraselmis chuii) pada Skala Laboratorium. J. Universitas Padjadjaran Fakultas Perikanan dan Ilmu Kelautan Jatinangor.

Salmin. 2000. Kadar Oksigen Terlarut di Perairan Sungai Dadap, Goba, Muara Karangdan Teluk Banten.Dalam : Foraminifera Sebagai Bioindikator Pencemaran, Hasil Studi di Perairan Estuarin Sungai Dadap, Tangerang (Djoko P. Praseno, Ricky Rositasari dan S. Hadi Riyono, eds.) P3O - LIPI hal 42 - 46

Sari, N. 2005. Pengaruh Rasio COD/NO3 pada Parameter Biokinetika Denitrifikasi Pengolahan Limbah Cair Perikanan dengan Lumpur Aktif. Skripsi. Bogor: Fakultas Perikanan dan Ilmu Kelautan-IPB.

Setyono dan Yudo, S. 2008. Potensi Pencemaran dari Limbah Cair Industri Pengolahan Ikan di Kecamatan Muncar, Kabupaten Banyuwangi. JIA. Vol. 4, No. 2:136-145.

Supranto, J. 2003. Statistik Teori dan Aplikasi. Edisi Lima Jakarta: Erlangga.

USEPA. 2002. Methods for Measuring the Acute Toxicity of Effluents and Receiving Waters to Freshwater and Marine Organism. US Enviromental Protection Agency: Washington DC.

Wijanarko, A., Hermansyah, H., Gozan, M., and Witarto, B.A., (2007), Pengaruh Pencahayaan Siklus Harian Terhadap Produksi Biomassa Chlorella vulgaris Buitenzorg Dalam Fotobioreaktor Kolom Gelembung, Jurnal Teknologi, 1, pp. 58-65. 